\title{
EL ORO EN EL BARROCO *
}

\section{Por Manuel González Galván}

Pocos estilos artísticos han dado tanta importancia al brillo y la abundancia áureos como lo ha hecho el barroco, es más, sin duda constituye la expresión de cultura con mayor número de monumentos en donde el oro tiende a recubrir por completo los interiores.

En lo que al mundo cristiano-occidental se refiere, la aplicación del oro alcanza su apoteosis y mayor densidad en los retablos barrocos entre los que destacan, por su significación, los de modalidad salomónica que, además, cubren una amplísima geografía que incluye desde el Cercano Oriente a toda Europa y culmina su abundancia en España y sus antiguos dominios americanos.

Puede decirse que la presencia del oro abundante, si bien, no es novedosa en la historia del arte, pues basta con recordar lo bizantino, sí alcanza en el barroco su mayor importancia al recubrir en forma total y sistemática determinados elementos arquitectónicos, preferentemente los retablos, y esto sucede con una clara y consciente intención alegórica donde se incorporan remotos y sugestivos antecedentes a un esplendor ornamental que sirve de apoyo a una intención didáctica y trascendente.

Como fuerza simbólica el oro reposa en el barroco con tan singular intemporalidad expresiva que no sería remoto ni es anacrónico decirlo, en otro tiempo, otro estilo y otro espacio, el más bello de los metales puede reargumentar su presencia como envolvente expresivo de anhelos espiritualistas pues, como fórmula iconográfica, el oro con sus cualidades, es autónomo de las formas artísticas que recubre.

\section{Valor simbólico}

Por medio de citas que haremos a continuación corroboramos la idea universal que se tiene del oro como emblema de lo perfecto, lo incorruptible y lo eterno y como, por ello, a través del tiempo el deseo de sobrevivencia y la muerte se asocia de varias maneras con él, así los faraones del antiguo Egipto encerraban literalmente sus cuerpos momificados en sucesivas cajas y sarcófagos de oro y en el lejano Tibet la carne

* Nota: las ilustraciones se obtuvieron del archivo fotográfico del I. de I. E. 
santificada de los monjes se forraba áureamente como nos lo dice un relato novelado:

Hombres que podían cubrir de oro la carne muerta. Trabajaban lentamente, colocando capa sobre capa del oro más delgado, más suave. Oro que fuera de Tibet costaba una fortuna, pero que para nosotros no tenf́a más valor que como metal sagrado... un metal que era incorruptible, y por lo tanto simbólico del estado espiritual final del hombre. 1

Cabe hacer notar la importancia simbólica del oro cuyas cualidades de permanencia e incorruptibilidad son muestra tangible del deseo religioso de eternidad sin importar su valor de transacción. De manera similar el mundo indígena prehispánico de América apreció el oro como representación de lo divino asociándole con el sol y la vida. Lo acumularon en los santuarios como Salomón lo hizo en su templo y acompañaron con oro los cuerpos sagrados, como en Egipto y Oriente. Asi nos lo deja sentir el Inca Garcilaso cuando describe el Coricancha o Templo del Sol en el Cuzco:

Todas las cuatro paredes del templo estaban cubiertas de arriba abajo de planchas y tablones de oro. En el testero, que llamamos altar mayor, tenian puesta la figura del Sol, hecha en una plancha de oro, el doble más gruesa que las otras planchas que cubrian las paredes... a un lado y otro de la imagen del Sol estaban los cuerpos de los reyes muertos, puestos por su antigüedad, como hijos de ese Sol, embalsamados que no se sabe cómo parecían estar vivos; estaban asentados en sus sillas de oro, puestas sobre los tablones de oro en que solian asentarse... Pasado el templo había un claustro de cuatro lienzos; el uno de ellos era el lienzo del templo. Por todo lo alto del dicho claustro había una azanefa de un tablón de oro algo más de una vara de ancho, el cual servía de corona al dicho claustro. ${ }^{2}$

Mucho podrfamos alargarnos rastreando esta acuménica idea del oro como materia que garantiza, con su presencia, el anhelo de inmortalidad universalmente compartido.

Dramático destino del brillo áureo es encarnar la angustia trascen-

1 Lobsang Rampa. El tercer ojo, lla. edición, Edit. Troquel. México, 1964, p. 234.

2 Inca Garcilaso de la Vega. Comentarios reales. Edición Riva Agüero, Madrid, 1929. 
dente y el rechazo a la muerte y al aniquilamiento que todo hombre guarda en lo más recóndito de su ser.

Grito agazapado, irreprimible, al que ni la insatisfacción agnóstica del pensamiento puede detener y así escapa en párrafos como los que, en noble prosa plasma Miguel de Unamuno: ${ }^{3}$

Cuando no se hacian para los vivos más que chozas de tierra o cabañas de paja que la intemperie ha destruido, elevábanse túmulos para los muertos, y antes se empleó la piedra para las sepulturas que no para las habitaciones. Han vencido a los siglos por su fortaleza las casas de los muertos, no las de los vivos; no las moradas de paso, sino las de queda.

Este culto, no a la muerte, sino a la inmortalidad, inicia y conserva las religiones.

No quiero morirme, no; no quiero ni quiero quererlo; quiero vivir siempre, siempre, siempre, y vivir yo, este pobre yo que me soy y me siento ser ahora y aquí, y por esto me tortura el problema de la duración de mi alma, de la mía propia.

¿Egoísmo decis? Nada hay más universal que lo individual, pues lo que es de cada uno lo es de todos. Cada hombre vale más que la humanidad entera, ni sirve sacrificar cada uno a todos, sino en cuanto todos se sacrifiquen a cada uno. Eso que llamáis egolsmo es el principio de la gravedad psíquica, el postulado necesario. "AAma a tu prójimo como a ti mismol", se nos dijo presuponiendo que cada cual se ame a sí mismo; y no se nos dijo: "IÁmate!", y, sin embargo, no sabemos amarnos.

Creo en el inmortal origen de este anhelo de inmortalidad, que es la sustancia misma de mi alma. Pero ¿de veras creo en eilo... ? y ¿para qué quieres ser inmortal?, me preguntas ...? ¿Para qué?, no entiendo la pregunta francamente, porque es preguntar la razón de la razón, el fin del fin, el principio del principio.

$Y$ aún si esa creencia fuese absurda 2 por qué se tolera menos el que se les exponga que otras muchas más absurdas aún?, ¿por qué esa evidente hostilidad a tal creencia?, ses miedo?, ¿es acaso pesar de no poder compartirla?

\section{La alquimia}

El hermetismo, lo esotérico y el sentido sacro de la alquimia, que proviene del remoto Egipto, es natural que proyecte en la idea del oro

8 Miguel de Unamuno. Del sentimiento trágico de la vida. Espasa-Calpe, S. A. México, 1952, pp. 39-46. 
sus mayores aspiraciones como plasmación o culminación de un proceso perfeccionista. Al concepto universal de eternidad e inmortalidad que en sí, suscita el oro, se asocia el de perfección por obra de la callada labor secular de la alquimia. No se imagina un alquimista si no es trabajando en un misterioso laboratorio donde constantemente se efectúan procesos de transmutación en busca de una quimera: la piedra filosofal. Creer que los alquimistas buscaban solamente convertir los metales pobres y opacos en oro para obtener riqueza material, es proyectar mezquindad y una limitada ambición espiritual que siempre ha estado vigente en todas las épocas, pero contra la que ellos Iuchaban.

La idea alquimista del oro y su obtención es básicamente la idea del perfeccionamiento personal y el método para llegar a ello. O sea, dicho con la mayor sencillez, ¿cómo hacernos perfectos?, ¿cómo volvernos de oro? Hilvanando párrafos de un estudio sobre la alquimia podemos extraer esta idea del oro como deseo, proceso y logro de perfección: 4

En realidad, la alquimia puede ser definida como el arte de las transformaciones del alma. Con ello no pretendemos negar que la alquimia conozca y realice también operaciones metalúrgicas, como la limpieza y aleación de metales, con los procesos químicos correspondientes; pero su verdadera obra -de la que todas estas manipulaciones no eran sino referencias externas, símbolos de orden práctico- era la transformación del alma. A este respecto, el testimonio de los alquimistas es unánime. Op. cit., p. 33.

"El cobre no descansa hasta convertirse en oro", dice el maestro Eckehart, al referirse al alma que añora su naturaleza inmortal. Por tanto, los alquimistas no pretendían, según se ha dicho, convertir en oro los metales ordinarios aplicando ciertas fórmulas secretas en las que sólo ellos creían. El que realmente deseaba esto, pertenecia a la clase de los llamados "carboneros", que, sin estar vinculados a la verdadera tradición alquimica, trataban de realizar la "Gran Obra" mediante el simple estudio de los textos, que entendían sólo superficialmente. Op. cit, p. 35.

Los alquimistas declaran una y otra vez que el mayor obstáculo que se levanta en su camino es la codicia. Este vicio es para su arte lo que la soberbia para la mística del amor o la obcecación para la gnosis; la codicia es el nombre más cercano al egoismo, la encadenación al propio yo, limitado y sujeto a las pasiones. Op. cit., p. 42.

Por tanto, la magia del oro deriva de su esencia sagrada, de su per-

4 Titus Burchardt. Alquimia. Plaza y Janes, S. A. Editores. Barcelona, 1971. 
fección cualitativa, mientras que su valor material tiene sólo una importancia secundaria. Op. cit., p. 20.

Durante los siglos medievales, el arte cristiano debió nutrirse, en alguna forma, de conceptos como los antecitados ya que son justamente los siglos de la magia y la alquimia. Por esto, mucho han buscado, y encontrado, numerosos investigadores, de hermetismo y alquimia, en los grandes monumentos medievales. "Esto explica y justifica las suntuosidades litúrgicas y los trasfondos áureos que, sobre todo, vienen a nuestra memoria en la prolongada secuencia bizantina, aún vigente en las iglesias orientales $y$, aunque lo querramos ignorar, en su contrapartida barroca de Occidente y que, si para una contemporánea y limitada visión materialista parecen excesos o derroches de poder clerical, o a lo sumo infundadas actitudes populares o de mala distribución de la riqueza, ello no invalida el derecho ancestral, y también actual o futuro cpor qué no?, de ver en el oro y hacer con él lo que el espíritu, liberado de la propiedad egoísta, quiera.

Así, el oro generosamente aplicado en ajuares litúrgicos y, sobre todo, en la permanencia accesible de la arquitectura religiosa de todos los tiempos y abierta a todos pasa a ser, desde el punto de vista material, verdadera propiedad comunal además del consiguiente regocijo estético y placer espiritual de los más avezados.

De esta manera el asombro popular califica su propio hechizo dando nombre específico a monumentos que han sido célebres por su esplendor. En el siglo v d. C., Antioquía es la tercera ciudad del mundo, después de Roma y Alejandría, pues ni la propia Bizancio alcanzaba entonces su extensión, faustomonumental y población. Su catedral fue llamada "la dorada" porque mosaicos con fondo áureo recubrían el interior de sus muros y el intradós de su gran cúpula central.

En otros casos, que son muy abundantes, la riqueza se concentra en las techumbres que así devienen significativas, pues la exaltación de fe acuña el centelleo dorado en lo alto y la religiosidad contempla los techos dorados de los santuarios como premonición de un "cielo" que habrá de ser eterno.

La basflica de San Apolinar "el nuevo", en Ravena, fue llamada así desde el año 856 en que se trasladaron a ella las reliquias del cuerpo de San Apolinar porque había sido saqueada la iglesia del mismo San

5 Fulcanelli. El misterio de las catedrales. Plaza y Janes, S. A. Editores, Barcelona, 1968. 
Apolinar in classe por Ios sarracenos, pero durante tres siglos, desde su construcción, San Apolinar "el nuevo", estuvo dedicado a San Martín y se llamó San Martín con "cielo de oro" por estar dorado su techo.

Pero, todo lo anotado hasta ahora no deja de ser una sugerente serie de coincidencias o cuando más actitudes religiosas que son similares, pero que no explican ni justifican en realidad y sólo sirven de antecedente a la enunciada y obsesiva presencia del oro en el barroco, especialmente en el del mundo hispánico. Para entender verdaderamente ¿por qué tanto oro en nuestros templos barrocos?, y ¿por qué la insistencia eclesiástica de sobredorar tanto ornato?, así como Łpor qué la católica indiferencia creando sus retablos omnidorados frente a la crítica acerba de un incipiente capitalismo ególatra que le era contemporáneo? La respuesta a estas interrogantes está en un proceso de investigación, lento pero confiado, que partió del siglo xvi, culminó en el xvir y llegó a su mayor realización plástica en el xvill.

Fue una búsqueda y un encuentro que tuvo a las escrituras sagradas como base, el templo que Salomón construyó en la antigüedad como antecedente y una literal actitud católica como visión histórica, ya que se buscó el pasado para actualizarle, hacerle presente y lanzarle al futuro con certeza de logros intemporales; esto es, que el depósito antiguo es crédito para necesidades futuras.

\section{Tratadistas europeos}

Tan amplio y vasto es el capítulo de los tratadistas europeos, que se interesaron por investigar las sagradas escrituras y extraer de ellas lecciones prácticas para aplicarse en la creación artística, que solamente mencionaremos algunos muy significativos para el proceso de aprecio, formación y difusión de ese "salomonismo" que da savia al movimiento barroco. ${ }^{8}$

Una vez concluido el Concilio de Trento (1545-1563), la Iglesia católica se propone una renovación general que afecta, desde luego, las expresiones artísticas, para las que se busca una inspiración más de raiz judeo-cristiana que la del clasicismo greco-romano pretendida por el Renacimiento. A la serie de tratadistas más, digamos, técnicos y laicos como son el romano Vitrubio y los renacentistas Palladio, Serlio y Vignola, se suceden los investigadores religiosos cuyas proposiciones

- Véase un importante resumen: en Francisco de la Maza. Cartas barrocas desde Cas. tilla y Andalucia. IIE. UNAM, México, 1963, pp. 39.49. 


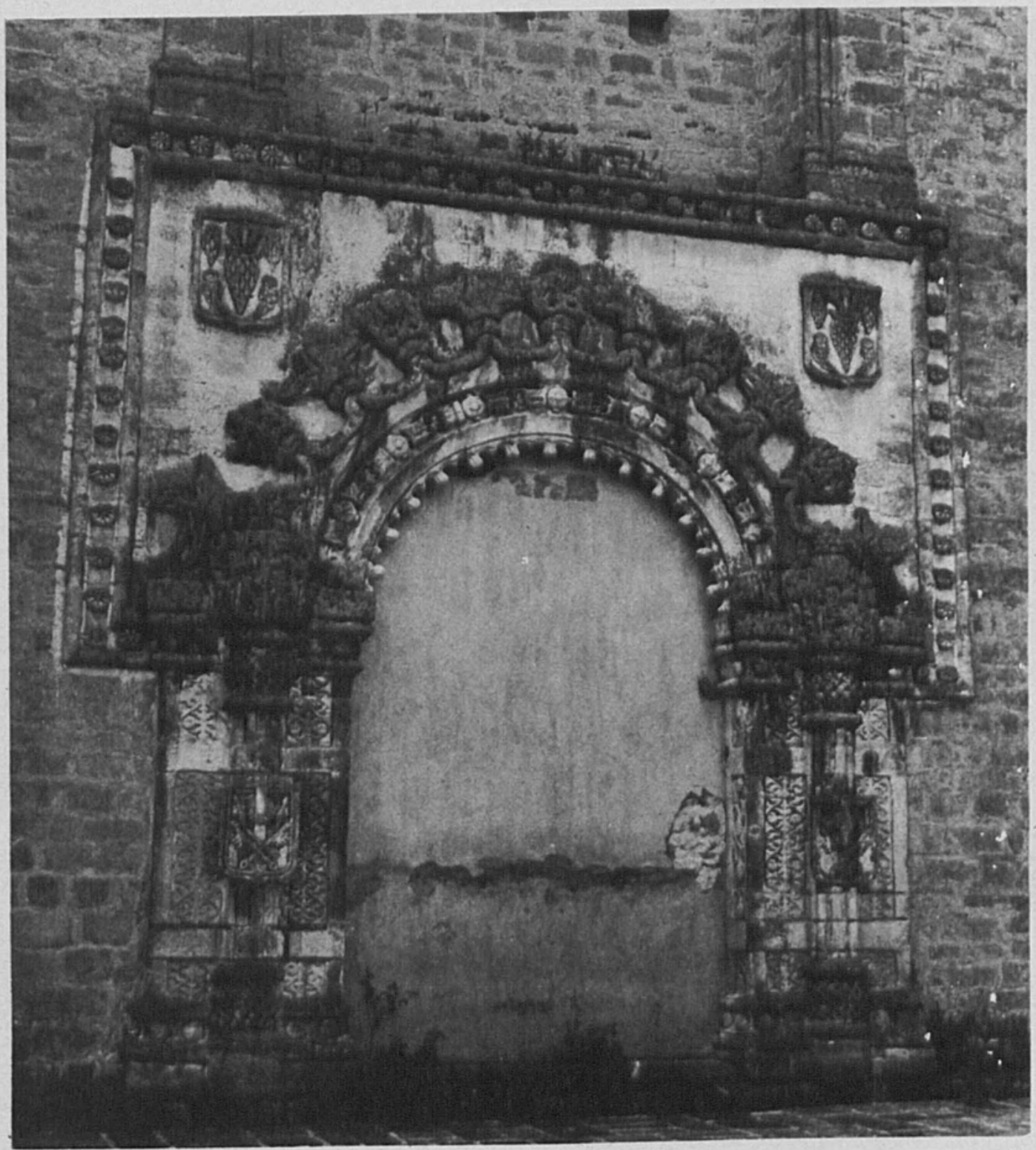

1. Huejotzingo, Pue. Portada de Porciúncula en la iglesia del Convento franciscano, siglo XVI. Resaltan las semicolumnas Jaquin y Boaz, sobre las jambas de la portada. 


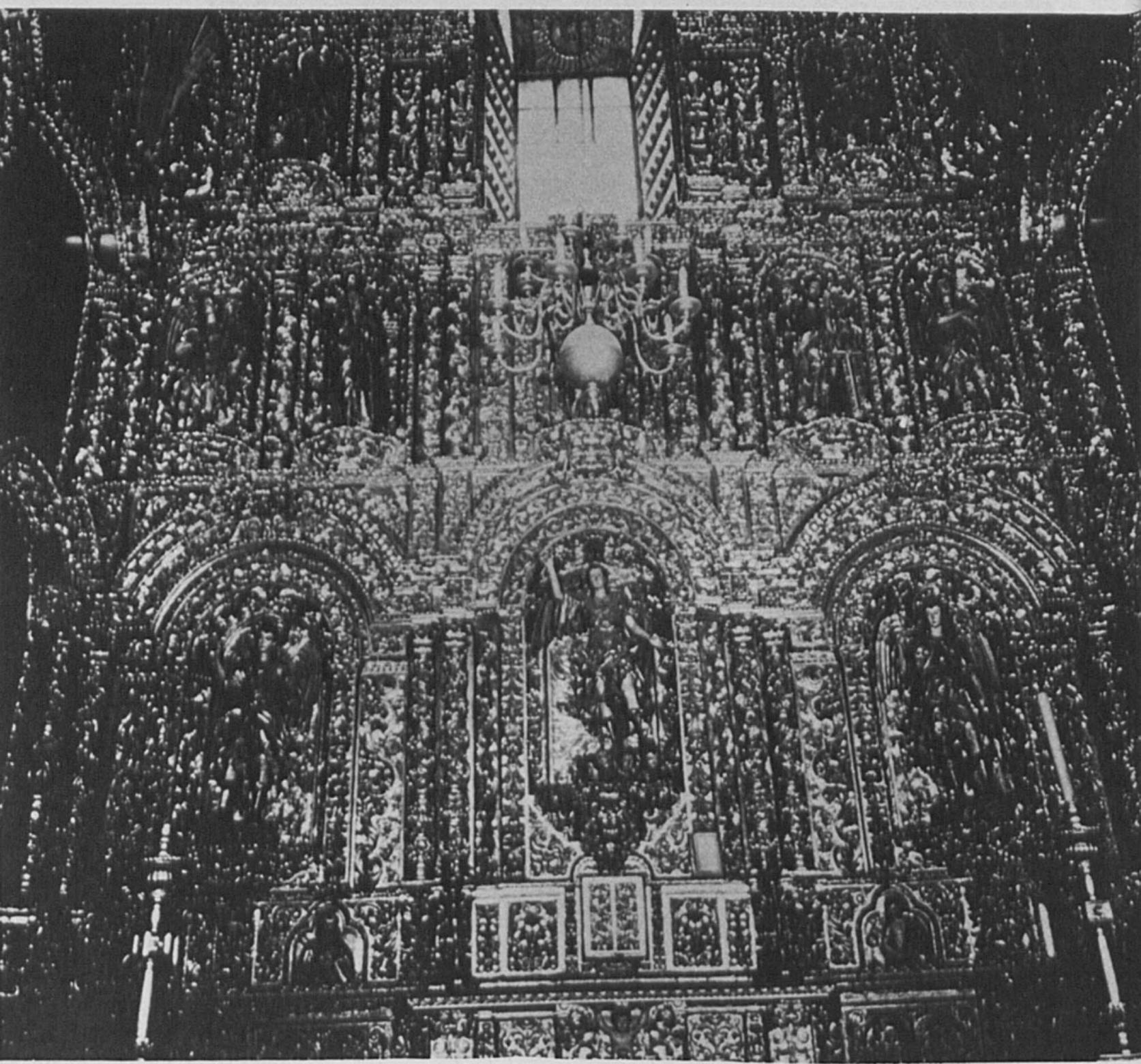

2. México, D.F. Capilla de los arcángeles en la Catedral Metropolitana. Retablos salomónicos del siglo XVII. Espacios limitados con el máximo esplendor. 


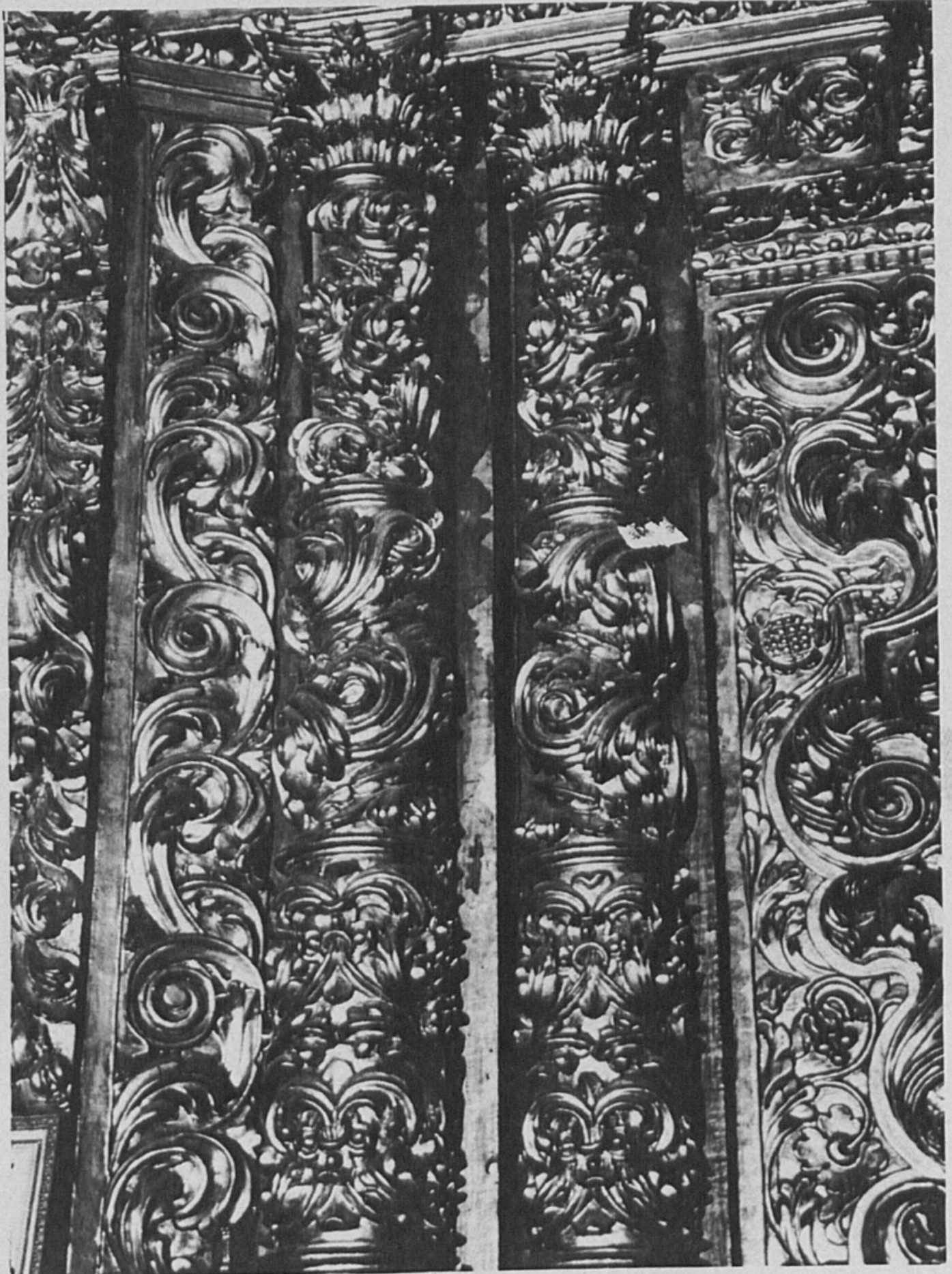

3. México, D.F. Capilla de los arcángeles en la Catedral Metropolitana. Detalle del retablo principal. Siglo XVII. El oro recubre totalmente las formas arquitectónicas y decorativas. 


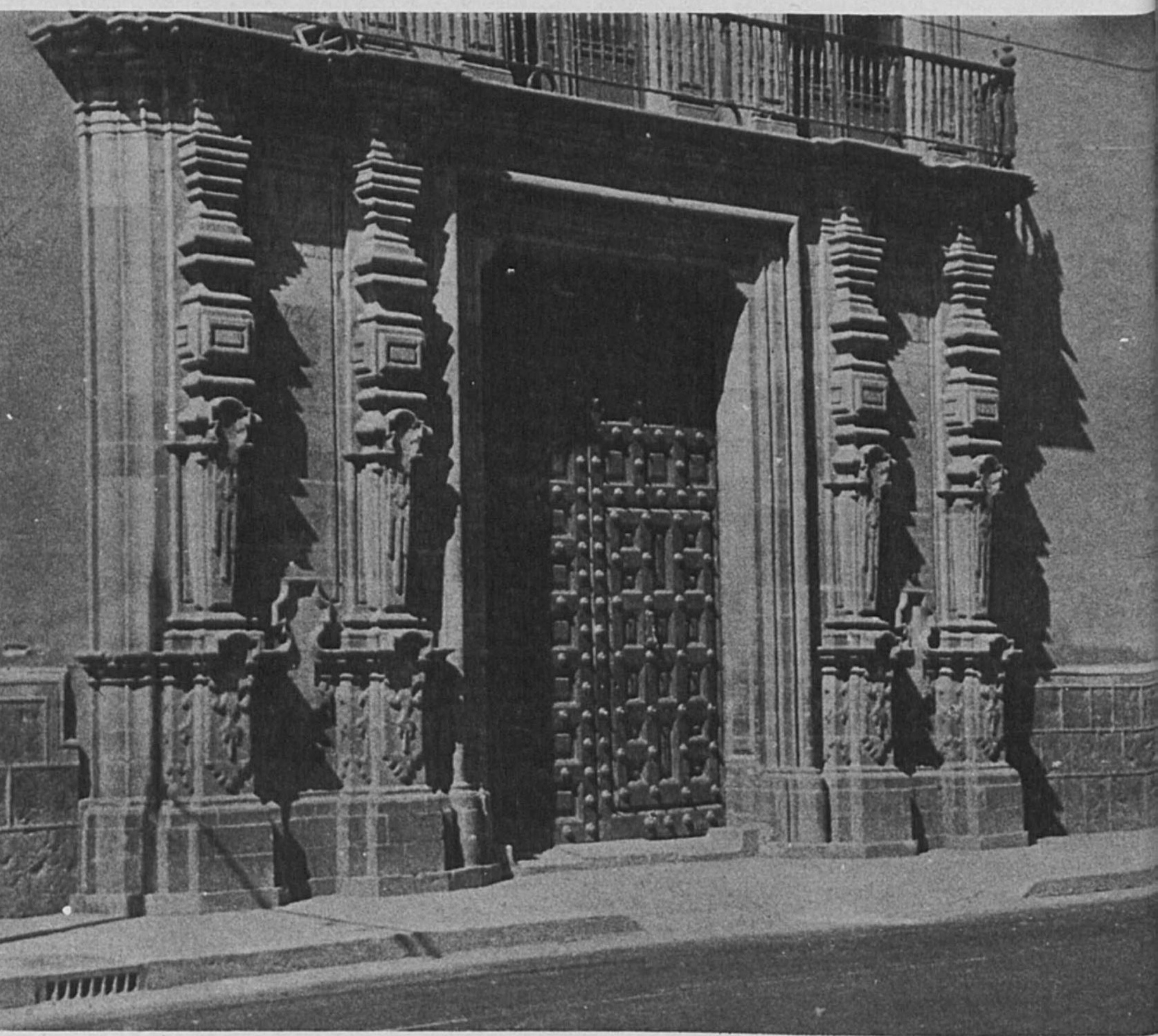

4. México, D. F. Portada del antiguo palacio arzobispal. 1743. En el paño de los interestípites se aloja la inscripción latina que alude a la renovación de todas las cosas. Aps. 21 (5). 


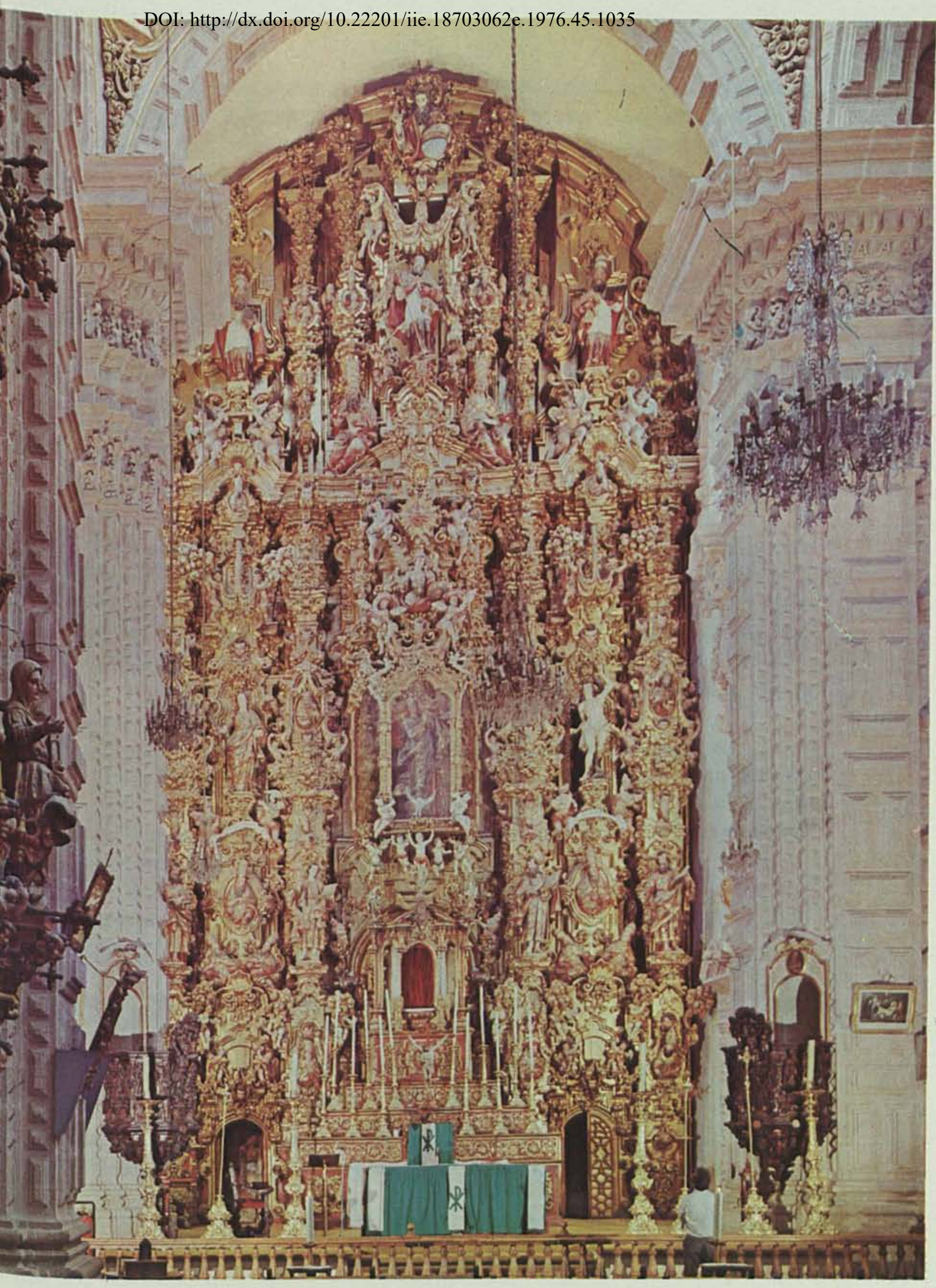

5. Taxco, Gro. Iglesia de Santa Prisca. Retablo mayor churrigueresco, construido en la segunda mitad del siglo XVHI. Las pilastras estípites, con su abstracción de la forma humana, constituyen una especie de plasmación artística de lo que los alquimistas deseaban ver realizado; la transustanciación del hombre en oro. 
DOI: http://dx.doi.org/10.22201/iie.18703062e.1976.45.1035 
de creatividad tendrán que ir naturalmente imbuidas de religiosidad. Al arte culto del Renacimiento le sucederá el arte santo del barroco sin demérito del momento crítico, ambivalente y plásticamente cada vez más definido en su personalidad, que es el manierismo.

Para el tema de nuestro interés simplemente glosaremos algunos títulos y autores en su secuencia cronológica.

En 1572, San Carlos Borromeo, uno de los principales promotores del Concilio tridentino, propone en su Instructionum fabricae un rechazo al clasicismo y una búsqueda de formas más acordes con la tradición religiosa; tal parece que al barroco se le desea antes de existir.

En 1577, el papa Gregorio xirr funda la Academia de San Lucas en Roma, con unos estatutos en los que se ve clara la intención de cambio y ruptura con el arte del Renacimiento $\mathrm{y}$, además, se deja sentir la acentuación de la iconografía didáctica, pues la Academia se pone bajo el patrocinio de un santo que sabe de arte ya que, según la tradición, San Lucas fue pintor.

Para estas fechas, fray José de Sigüenza, el cronista del Escorial, considera y llama al gran monumento español "otro templo de Salomón", tanto que la tendencia a marcar cuadrados y formar volúmenes y espacios cúbicos en el magno conjunto no es pura coincidencia, puesto que el Sancta Sanctorum del templo jerosolimitano fue justamente un cubo: "El debir tenía veinte codos de largo, veinte codos de ancho y veinte codos de alto." Reyes, 1-6. 20.

$Y$, en el "Patio de los reyes" escurialense, las seis grandes estatuas y las inscripciones latinas de sus pedestales hacen una muy clara alusión al templo de Jurusalén como antecedente de este nuevo templo que en cierta forma lo repite, restaura y supera como lo hará más adelante, en forma general, el barroco.

Se deja entrever, como programa histórico-estético-religioso, toda una secuencia oculta en la lectura de las regias inscripciones como puede verse en la lectura traducida de las mismas:

\section{David: Operis exemplar a Domino recepit.}

Recibió del Señor el modelo del templo.

Salomón: Templum domino aedificatum dedicavit.

Dedicó al Señor el templo que le edificara.

Ezequías: Mundata domo phase celebravit.

Habiendo restaurado y limpiado el templo, celebró la Pascua. 
Josías: Volumen Legis domino invenit.

Encontró el volumen de la ley del Señor.

Josafat: Lucis ablatis legem propagavit.

Destruidos los bosques idolátricos, propagó la ley.

Manasés: Contritus altare domini instauravit.

Arrepentido, restauró el altar del Señor.

En 1593, Benito Arias Montano estudia la reconstrucción ideal del templo de Salomón en su Antiquitatum Iudaicarum, principalmente interpretando los libros de los Reyes y el libro de Ezequiel.

En 1604, el jesuita Juan Bautista de Villalpando, en su obra De Postrema Ezechielis prophete visione, publicada en Roma, continúa este tipo de estudios y llega, como consecuencia, a censurar a la misma Roma porque ella destruyó el templo de Salomón y es más, opone a los órdenes clásicos este nuevo orden deducido que él llama "orden armónico".

Es fácil darse cuenta del gran giro que ha dado el arte en el curso de un siglo, al escoger sus fuentes de inspiración, pues si en $1504 \mathrm{Bra}$ mante proponía a Julio II el modelo del nuevo San Pedro con apoyo en la tradición y los órdenes clásicos, exactamente un siglo después, y en la misma Roma, el padre Villalpando rechaza tales órdenes para en su lugar colocar este distinto "orden armónico" con un crédito de antigüedad aún mayor que el del mundo clásico y con la ventaja religiosa de provenir de inspiración divina. $?$

En 1613, Juan de Pineda, también jesuita, estudia a su vez el templo salomónico en De rebus Salomonis regis libri octo.

En 1617, otro jesuita; Martín Esteban, contribuye con su obra Compendio del rico aparato y hermosa arquitectura del templo de Salomón no sólo a difundir este salomonismo ya aceptado y vigente en esas fechas, sino a que se identifique la frecuencia de escritores jesuitas sobre el tema del templo santo con la promoción que del consecuente

7 Para conocer las ideas del padre Villalpando debe verse de René $C$. Taylor "El padre Villalpandio y sus ideas estéticas", Anales 3, Boletín de la Real Academia de Bellas Artes de San Fernando, III época, vol. I, núm. 4, Madrid, 1952. 
estilo hace la misma orden para que, especialmente en la zona centroeuropea, el barroco llegue a llamarse: "arte jesuftico".

En 1639, finalmente, en el Arte y uso de arquitectura, de fray Lorenzo de San Nicolás, se resumen muchas de las búsquedas anteriores en un tratado que ya da fórmulas y soluciones prácticas. Es también, 1683, el año en que Bernini concluye el Baldaquino de San Pedro, obra "salomónica" de gran importancia, ya que si bien no es la primera como manifestación de la nueva modalidad artística, sí se levanta en el preciso corazón de la catolicidad; sobre la tumba del primer papa y bajo la colosal cúpula renacentista; desde tan eminente lugar, irra. diará en adelante una larga influencia consagrando y reafirmando, con el movimiento helicoidal de sus columnas, el nuevo estilo de inspiración y agrado divinos.

Será por último, que hacia 1655 , fray Juan Rizzi, benedictino nacido en Madrid de padre italiano, refunda y consigne en España lo logrado por este amplio movimiento que desde mediados del siglo xvi, a mediados del xviı, tardó prácticamente un siglo en verse realizado. Con Rizzi adquiere también, ya madura la modalidad, su nombre definitivo como "orden salomónico" en su Breve tratado de architectura acerca del orden salomónico entero. ${ }^{8}$

\section{Presencias en América}

El salomonismo, por ser un movimiento surgido y difundido básicamente en el mundo católico, es indudable que tiene repercusiones importantes en la América española y a todo lo largo y ancho del continente evangelizado por España. Hubo evidencia de ello, desde luego recrudecido en determinadas regiones, sobre todo donde se dieron las manifestaciones culturales indígenas más vigorosas con anterioridad a la conquista.

Como una prueba de lo anterior, y por sernos lo más cercano, solamente anotamos algunos datos en que el salomonismo se manifiesta en la Nueva España y, obviamente, esto no quiere decir que sea exclusividad regional, ni mucho menos el que éstos sean los mejores casos.

8 Los manuscritos de fray Juan Rizzi: Pintura sabia y el Breve tratado de architectura acerca del orden salomónico entero, permanecieron inéditos hasta 1930, en que los publicó en Madrid Enrique Lafuente Ferrari, precedidos de un estudio. 
En un magnífico artículo, Santiago Sebastián, nos descubre como el salomonismo, vigente y operante desde el siglo xvr, se plasma en una obra de arquitectura. ${ }^{\circ}$

De su estudio extraemos dos párrafos definitivos:

Si ahora vamos a destacar el hecho insólito de la presencia de las columnas de Jaquín y Boaz en la portada de la iglesia del convento franciscano de Huejotzingo, en Méjico del siglo xvI, no lo hacemos para consignar un hecho poco frecuente sino sobre todo para ver cómo esta imagen se corresponde con un fenómeno de la ideología franciscana, expresada principalmente en la Historia eclesiástica de fray Jerónimo de Mendieta (1525-1604).

Una constante de los escritos de este misionero franciscano es el paralelismo que establece entre el Antiguo Testamento y la realidad americana, p. 77.

Parece evidente que el franciscano que pensó la alusión al templo de Salomón no lo hizo por mera nostalgia arqueológica sino más bien respondiendo a una problemática de tipo espiritual como sugerimos al principio de este trabajo. Todo era posible, pues, como lo ha destacado René Taylor, el templo de Salomón no sólo fue considerado como un edificio perfecto, sino que ante todo poseyó un gran valor simbólico ${ }^{10}$ (figura 1).

Como parece ser, fueron los franciscanos los primeros y principales difusores de estas ideas pero no los únicos, ya que escritores de otras órdenes también trabajaron sobre ello. Como ejemplo en el siglo xvir descuella la obra del carmelita fray Andrés de San Miguel. ${ }^{11}$

Aproximadamente en 1630 fray Andrés inicia la redacción de su manuscrito que no es sino una miscelánea de historia, teoria de la arquitectura, matemáticas, geometrfa y otras disciplinas, $y$ que por su heterogeneidad resulta representativa de la cultura técnica de su época y de la manera de tratar las ciencias, con el mérito de haber sido escrito en estas tierras.

Para nuestro tema, es importante comprobar cómo se tenía en América un conocimiento e interés paralelo a lo europeo y que, en el

9 Santiago Sebastián "La sígnificación salomónica del templo de Huejotzingo (Méjico)". Traza y Baza. Cuadernos Hispanos de Simbologia, Arte y Literatura, núm. 2, Palma de Mallorca, 1973, pp. 77-88.

10 René C. Taylor, op. cil., p. 422 (nota 7).

11 Obras de fray Andrés de San Miguel. Introducción, notas y versión paleográfica de Eduardo Báez Macias, IIE. UNAM., México, 1969. 
primer tercio del siglo xvir, el salomonismo tiene una primordial presencia para la creación arquitectónica. El solo enunciado o encabezado de los primeros cinco capítulos de la obra, aparte del jugoso texto, nos lo deja saber.

El primer capítulo es "Descripción del templo de Salomón", e -insistimos- es jel primer capítulo!; naturalmente aunque no hace citas directas se apoya en las Sagradas Escrituras, pero pone mucho de su cosecha como el hacer el cambio de valores y calcular que Salomón, para construir el templo, heredó de David "ochocientos millones de ducados de los que ahora se usan". El segundo capítulo es complemento del primero al tratar "De otros edificios que estaban alrededor del templo". El tercero, refiriéndose de nuevo al templo salomónico, parece una premonición de lo que, a su vez, pasó con la obra y el esplendor barrocos, es decir, tras el asombro de su riqueza viene el sentimiento por su pérdida, así en este capítulo escribe acerca "De los grandes tesoros y riquezas que puso Salomón en el templo y el fin que tuvieron". El cuarto capítulo llamado "De algunos templos que hubo en el Perú y de sus riquezas y ornato", resulta de gran interés por la curiosa mezcla de legendaria arqueología americana entreverada con salomonismo escriturístico y un orgullo americanista en ciernes, que el barroco, justamente, habrá de plasmar a partir de esta época, por eso extraemos de su entusiasmo algunos párrafos:

Pero si con ojos desapasionados y no con los que algunos miran las cosas de los indios, teniéndolas en poco, queremos mirar la hermosura y curiosidad de los templos que estos gentiles occidentales tenían, veremos que son no sólo en edificios, sino en riquezas, de los más aventajados del mundo. Si lo queremos notar, en cuanto a su grandeza, excedía el de México al de Busiris, del cual se dice que tenía de circuito mil seiscientos y veintiocho pasos, y el referido de México tenía más de tres mil y de alto más de cien varas. $O p$ cit., p. 98.

Pasada la provincia de Pasta, hacia la de Quito, habla un grande y riquísimo templo, en el cual se ven las señales de las planchas que de oro y plata hubo en las paredes, donde también hubo grande suma de vasos, de lo mismo, en que echaban los vinos y las demás cosas de los sacrificios y servicio del mismo templo. Nunca se vio semejante género de vasos de oro en el mundo para el servicio, ni en el templo de Salomón, de los cuales dice la Sagrada Escritura que 
eran de metal, y no sólo eran estos vasos muchos en grandisima suma, sino que eran rica y curiosamente labrados y adornados (op. cit., p. 98$)$.

Revaloración de la grandeza indígena, orgullo de ella y comparación relativa entre dos antigüedades: la americana y la escriturística se reiteran en el escrito de fray Andrés, pero puntualiza la superior maravilla del templo salomónico:

Al fin quiso Dios enriquecer y engrandecer a Salomón y a su templo, de su mano, sobre todos los reyes y templos del mundo aventajadísimamente,... y los demás templos famosos del mundo se deben considerar de manera que nunca llegaron a llenar el deseo de sus fundadores porque a Salomón le sobraba poder, saber y voluntad de hacerlo y lo hizo como quiso y con traza revelada, y semejante sabiduria y traza faltó a todas las demás obras famosas del mundo y así en todo quedaron muy cortas si se comparan con el famoso templo de Salomón, así en edificio como en riquezas (op. cit., p. 100).

Queda implícito, por lo anterior, que sólo por inspiración divina y mayor riqueza podrá superarse el templo del Señor y esto es lo que incita al barroco en su recrudecimiento de simbolismo y riqueza.

El quinto capítulo nos instruye e indica:

Cuáles han de ser nuestros templos, a imitación de la vida de Jesús Nuestro Señon, con algunas autoridades y ejemplos que nos dejaron los santos.

Y... tenfa que aparecer el viejo conflicto; la "querella iconoclasta" siempre latente y nunca bien superada. Esa ocasión de escándalo por el contraste o conjunción de sencillez y grandeza, de certera dialéctica entre pobreza y riqueza o, en última instancia, el discernimiento entre lo falso o verdadero que surge de la relación entre humildad y soberbia.

Nuestro fray Andrés, desde luego recomienda la pobreza en los monasterios y la sencillez en las iglesias de los mismos para apegarse a los votos y constituciones de las órdenes, especialmente al referirse a la suya carmelitana, pero ésta desde luego no involucra los templos que en forma más genérica no sólo son el "templo del Señor" sino "casa del pueblo de Dios" como las catedrales, parroquias y cualquier san- 
tuario o mínima capilla en que se rinde culto a la divinidad, y aun para los templos monásticos se deja la puerta abierta, sin dogmatismos, a una razonable suntuosidad, pues nos apunta una cita de las constituciones de Santo Domingo que dice:

Nuestros frailes tengan sus casas humildes en una medianía y no se hagan ni consientan hacer en nuestros monasterios curiosidades ni superfluidades notables en la escultura ni en la pintura, ni en patios ni en cosas semejantes que afean nuestra pobreza; mas en las iglesias podráse permitir (op. cit., p. 102).

Siendo nuestra época propicia a la iconoclastía y la pobreza de los templos, es oportuno insistir ahora en que la iglesia como tal, como eclessia o asamblea de fieles no tiene ninguna referencia escriturística ni prohibición evangélica expresa para la riqueza en los santuarios dedicados al culto. Hay una prohibición de la idolatría a las imágenes, muy marcada en el Antiguo Testamento, por la obvia influencia que podría tener sobre el pueblo de Israel el estar rodeado de pueblos idólatras, y los evangelios promueven la pobreza y el desprendimiento de bienes materiales en lo personal para beneficio del prójimo y del perfeccionamiento propio, pero en ningún momento prohíben la riqueza en el culto, es más, ni lo mencionan. Por tanto la pobreza de los templos es recomendable, sobre todo cuando el propio pueblo la padece al construirlos, pero de ninguna manera es obligada cuando el mismo pueblo generosamente dona o acumula riqueza para satisfacer un deseo colectivo de ofrenda.

Sin embargo, como uno más, entre los numerosos casos de rechazo y aceptación, que de la suntuosidad se han dado dentro del arte cristiano, recordamos la pugna monacal del siglo xir entre cistercienses auteros y clunyacenses pródigos. ${ }^{12}$

Del libro de Werner Weisbach sobre Reforma religiosa y arte medieval, extraemos párrafos aclaratorios de la siempre importante discusión:

Si se considera desde este aspecto el papel que juega el atrevido edificio de Cluny iI y se consideran las propiedades artísticas que en él habia, seguramente habrá de estimarse su significación como muy

12 La trascendencia que para la historia del arte occidental tuvo esta divergencia la estudia con detenimiento Weisbach en un muy documentado libro: Werner Weisbach. Reforma religiosa y arte medieval. Espasa-Calpe, S. A. Madrid, 1949. 
alta. Ello fue, como es sabido, lo que dio motivo para que San Bernardo de Clairvaux, en la célebre carta al abad Guillermo (h. 1124), lanzara su ataque contra el arte eclesiástico de su tiempo. Pues sólo puede haber pensado en Cluny cuando critica en las iglesias "la enorme altura, la longitud desmesurada, la anchura superflua, las costo. sas decoraciones y pinturas que estimulan la curiosidad, que distraen a los que meditan de su piadosa concentración atrayendo a sí sus miradas". "... Q Qué tiene que buscar el oro en la iglesia!", exclama. Pero establece una distinción entre iglesias episcopales y monacales. Habla como monje a los monjes. Los obispos, que tienen que ejercer su cura pastoral sobre consagrados y no consagrados, cuando no pueden despertar al pueblo laico, prisionero de la carne, con riquezas espirituales, pueden hacerlo con las materiales. Pero a los monjes, que han salido fuera del pueblo laico, que han renunciado por motivo de Cristo a todas las cosas carnales, materiales y ricas, no les acomoda lo mismo... (op. cit., p. 77).

$Y$ proseguimos, con Weisbach, en la defensa que otro monje ilustre, poco posterior a San Bernardo, hace del aparente lujo de los templos y el culto:

No es posible hacer ver con mayor claridad los contrastes que tocante a esta cuestión se daban dentro de la iglesia católica, que atendiendo a las manifestaciones que hace Ruperto, abad del monasterio de Deutz (desde 1210), un apasionado partidario de la reforma y, como Bernardo, representante de una sociedad mística, en su escrito De divinis officiis. En contradicción con los ataques de Bernardo, entiende justificar con argumentos teológicos el uso de la pompa y ricos adornos. Dice en el capitulo 23, De ornatu altaris et templi: "aun cuando el divino principio interior de la misa celebrada en el altar irradie una claridad inagotable, sin embargo, es siempre santo lo que toca a los vasos sagrados, al adorno del altar y de sus servidores, pero más brillante en determinados momentos, según la significación del dia. Los días festivos resplandece el servicio divino con oro, plata y piedras preciosas, en cada caso según las posibilidades de los creyentes, y aun cuando estas cosas sean adornos desde el punto de vista mundano, son, desde el punto de vista eclesiástico y divino, limosnas de la piedad. No porque Dios reciba con mayor agrado los objetos de oro que los ordinarios, ni los adornados con piedras preciosas que los despojados de toda decoración, sino porque los hombres, cuando se desprenden de aquello que aprecian para ofrecerlo a Dios ale- 
gremente por su amor, le ofrecen algo precioso, sea lo que fuere. Y puesto que ellos aman el oro, que atrae más que otra cosa el ansia de la carne y de los ojos, cuando ofrecen a Dios esto que él no necesita ... , hacen, sin duda, una obra santa y agradable a Dios". Como testimonio evangélico para esta concepción se cita también a la pecadora que unge con preciosos ungüentos los pies de Cristo. Por lo demás, donde hay ocasión y medios para ello, el propio Dios ha dado el encargo de labrar con oro y plata y el mayor arte posible (Éxodo, $\mathrm{xxx}, \mathrm{xxvı}, \mathrm{xxvil}$, op. cit., p. 78).

No debemos pasar por alto que, por circunstancias sociorreligiosas, particulares de la América española, prácticamente no existieron aquí, en la época colonial, iglesias de clausura que fueran exclusivas para frailes o monjas, sino que todos los templos monacales se abrieron al pueblo, a una feligresía que gustaba de esplendores, riqueza de ornato y abundancia de imaginería que sirve para distraer sí, pero enseñando.

Los antiguos temores o reservas monacales respecto al arte, antes considerados, con todo $y$ ser tan respetables, resultaban inoperantes en el momento de erigirse el barroco.

Ahora bien, retomando el hilo de nuestro salomonismo, durante el siglo xvil nos encontramos con que los frailes continúan fomentando su importancia.

Son los agustinos, tan dados al monumentalismo, desde el siglo XVI quienes insisten en considerar lo hecho aqui como continuidad y actualización de la antigüedad escrituristica.

El cronista de la orden agustina, fray Diego Basalenque, 18 escribió su obra en 1644, aunque se publicó hasta 1673. En pleno siglo xviı se refiere a fray Juan de Utrera quien comenzó en el siglo xvi la construcción del convento agustino de Ucareo diciendo que como "diestro arquitecto hizo lo que los oficiales y maestros del templo de Salomón". Cuando relata "que el convento de Tiripetío fue la casa donde se pusieron los primeros estudios mayores de nuestra orden, de toda la Nueva España" y que para ello fueron enviados como maestros y lectores los padres S. Román y P. Chávez, asienta:

Confesamos asimismo que estos dos padres fueron aquellas dos columnas hermosas y bien labradas de bronce, que Salomón puso en su templo, llamando a la una Fortaleza, y a la otra Perpetuidad; y

13 Diego Basalenque. Historia de la Provincia de San Nicolds Tolentino de Mi. choacán. México, 1973, cap. 16. 
decimos que esta Provincia, por haber sido fundada sobre dos columnas de bronce, con la gracia de N. Señor, es una de las provincias ilustres, y hermosas, que tiene nuestra religión, y que por la misma gracia de N. Señor, durará y se perpetuará en su ser, y hermosura, por estar fundada sobre columnas tan fuertes, y sólidas en santidad (op. cit., cap. 16).

Esta comparación entre personas, arquitectura y virtudes no es novedosa, ya que el propio Cristo así lo hizo comparándose El mismo con el templo de Jerusalén:

-Destruid este templo, y en tres dias lo levantaré. Replicaron los judíos:-Cuarenta y seis años se han empleado en edificar este templo ¿y tú vas a levantarlo en tres días? Pero el hablaba del templo de su Cuerpo. Cuando resucitó de entre los muertos se acordaron sus discípulos de que habia dicho esto, y creyeron en la escritura y en la palabra que Jesús había dicho (San Juan, cap. II, 19-22).

Es innecesario ponderar la importancia de esta cita evangélica, pues ella dio lugar, en toda la historia del arte cristiano, a una directa alusión simbólica entre los templos y el cuerpo de Cristo.

Ya entrado el siglo xviri, y cuando arquitectónicamente la modalidad barroca salomónica de columnas helicoidales, empezaba entre nosotros a ceder lugar a la por entonces más novedosa modalidad churrigueresca, o sea, al uso de la pilastra estípite, otro cronista agustino, fray Matías de Escobar, con una prosa llena de retruécanos barrocos y una obsesiva idea de concordancia entre hechos recientes y la antigüedad bíblica constituye un rico filón de donde extraer frases que comprueban la vigencia del salomonismo dieciochesco y así lo vemos en su Americana Thebaida, fechada en 1729. ${ }^{14}$

Fray Matías de Escobar explica la grandeza material de las iglesias como una consecuencia de lo obrado con grandeza de corazón:

digo ya que Nuestros sabios Salomones habiendo levantado por millones espirituales templos a Dios; tantos, cuantos ignora el guarismo; dispusieron levantar materiales casas para Dios, tan grandes, que ellos fuesen prueba manifiesta de los grandes corazones muy preciados

14 Fray Matias de Escobar. Americana Thebaida. Crónica de la provincia agustiniana de Michoacán. Balsal Editores, S. A., Morelia, México, 1970. 
de obras maquinosas, confesándose por menores a vista de los pasados. Op. cit., p. 107.

Los "millones de espirituales templos a Dios", fueron los indigenas convertidos, usados como símbolo, y así también los frailes fueron los "sabios Salomones" que levantaron los templos materiales.

$\mathbf{Y}$ como de oro tratamos aquí, el padre Escobar juega con el significado del nombre de Tiripitío, "lugar de oro" en idioma purépecha y nos dice que habiéndose establecido la primera casa de estudios mayores en la Nueva España, por los agustinos de Tiripitio, "nació la sabiduría en el oro de Tiripetío", op. cit., p. 121. Con lo que reafirma otra de las virtudes que desde la Edad Media se asocian con el oro: la sabiduria.

En el capítulo xL de su crónica, en el que se habla "De la fundación del cuarto convento de esta provincia llamado San Pablo Yuririapúndaro", se refiere a su insigne constructor, fray Diego de Chávez nombrándole, muy graciosamente, "Indiano Salomón", op. cit., p. 316, y de fray Francisco Cantillana, quien posteriormente a Chávez hizo la decoración del templo, dice que:

Doró toda la Iglesia, vistiéndola como allá Salomón el Templo de planchas de oro, este Salomón Mechoacano de panes de oro. Acóntecióle estando dorando el templo, caer de las nubes un rayo que se consumió lo más de lo dorado, a lo cual sólo dijo: que se prosiga en la obra, que es señal le es al Señor agradable este obsequio, puesto que baja fuego del Cielo a recibir el sacrificio (op. cit., p. 319).

Aún pues, los accidentes o fenómenos naturales adquieren ese tono alegórico que todo lo impregnaba.

Por consecuencia final, el salomonismo, surgido desde mediados del siglo xvi, con el transcurso de dos centurias llega al siglo xvin dejando una cauda de obras maravillosas que refulgen, en toda la geografía del mundo católico y aún más allá de él. Obras cuya presencia dorada se apoya y justifica en un sustrato de erudición y símbolo catalizados por la fe. En plena madurez, la modalidad salomónica del barroco, comparte su milenaria herencia de pensamientos áureos, con las otras facetas que el estilo muestra y así la obligada inundación de oro rebota en los muros benditos y se fragua en las espumas refulgentes de los retablos sin discriminar jerarquías de los santuarios ni expresiones formales regionales. Musgo solar que todo lo invade, y hace vibrar el espacio con átomos de eternidad. 
Así las demás variantes formales del barroco no necesitan justificar ni pelear sus recubrimientos áureos, como en el caso novohispano del churrigueresco, las formas nacen, por derecho, y obligaciones ancestrales, ungidas y consagradas por este real recubrimiento de sabiduría e inmortalidad.

\section{El templo de Salomón}

El corolario final de todo lo antedicho es preguntarnos, como se lo han preguntado tantos y a través de tantos siglos: ¿cómo sería el templo de Salomón? Y la respuesta, como también desde hace siglos, nos la dan las Escrituras. Respuesta fragmentada como un rompecabezas al que faltan piezas definitorias, pero así esta figura simbólica del templo del Señor, en su desaparición lleva su permanencia, pues queda como intemporal sugerencia en la que la fantasia abreva sin quedar sujeta.

Por tal razón, y como el esquema de este trabajo se ha ido armando a base de una recopilación de citas, terminaremos con una inmersión entre fragmentos de textos sacros donde el oro resuena y se repite como palabra con ecos de infinitud.

No debemos pasar por alto, una vez más, que el esplendor y la riqueza material en el culto divino, no se contraponen con una elevada espiritualidad y que desde la antigüedad, el severo monoteísmo hebraico así lo consigna, lo que constituye un antecedente no sólo del templo construido por Salomón sino de la censurada riqueza cultural más próxima a nosotros del barroco, acusado por la iconoclastía protestante de "idólatra" porque como dicen las escrituras:

No tendrás otro Dios que a mí. No te harás imágenes talladas, ni figuración alguna de lo que hay en lo alto de los cielos, ni de lo que hay abajo sobre la tierra, ni de lo que hay en las aguas debajo de la tierra. No te postrarás ante ellas, y no las servirás, porque yo soy Yavé, tu Dios, un Dios celoso... (Exodo 20 3-5).

Yavé dijo entonces a Moisés: "Ve, baja, que tu pueblo, el que tú has sacado de la tierra de Egipto, ha prevaricado. Bien pronto se han desviado del camino que les prescribí. Se han hecho un becerro fundido y se han prosternado ante él, diciendo: Israel, ahí tienes a tu dios, el que te ha sacado de la tierra de Egipto (Éxodo 32 7-8).

Volvióse Moisés a Yavé, y le dijo: "OOh, este pueblo ha cometido un gran pecado! Se han hecho un dios de oro. Pero perdónales su 
pecado, o bórrame de tu libro, del que tú tienes escrito". Yavé dijo a Moisés: "A él, que ha pecado contra mí, es al que borraré de mi libro" (Exxodo 31-33).

Pero como se ve, la prohibición y el castigo es por "adorar" las imágenes como si ellas fueran Dios, como en el caso del becerro de oro; una reminiscencia del culto egipcio al buey apis. Era pues muy necesario, en ese momento histórico, desechar las imágenes alusivas a otras divinidades para preservar el monoteismo del pueblo israelita.

Mas, el propio Moisés por mandato divino pide después oro y joyas para la "Casa del Señor", cuando esto tiene un sentido de ofrenda:

Moisés habló a toda la asamblea de los hijos de Israel, y les dijo: "He aquí lo que ha mandado Yavé: tomad de vuestros bienes, para hacer ofrenda a Yavé" (Exodo 35 20-22).

Vinieron todos los de corazón generoso, y todos aquellos a quienes impulsaba su ánimo a ofrecer, dones a Yavé para la obra del tabernáculo del testimonio y todo cuanto para el culto y las vestiduras sagradas era necesario. Vinieron hombres y mujeres, y todos los de ánimo dispuesto ofrecieron pendientes, arillos, anillos, cadenas, brazaletes y toda suerte de objetos de oro, presentando cada uno la ofrenda de oro que dedicaba a Yavé (Éxodo 35 20-22).

Pero un día los que hacían las obras para el santuario dejaron el trabajo y vinieron a decir a Moisés: "El pueblo trae bastante más de lo que se necesita para hacer lo que el Señor ha mandado" (Exodo 36 4-5).

He aquí, la respuesta más cumplida a las censuras dirigidas contra los santuarios que se levantan con riqueza, y más aún cuando esa censura parte de una actitud egoísta donde lo único que se ofrece es una negativa, frente a la generosa y espontánea dádiva del pueblo que alegremente y aun cuando tenga, en muchos casos, necesidad de esos bienes materiales, "trae bastante más de lo que se necesita para hacer lo que el Señor ha mandado". Espectáculo de entrega del que nuestro pueblo da prueba constante y para el que ha habido casos en que, como en los tiempos bíblicos "se impidió al pueblo traer más. Lo reunido bastaba y sobraba para todo lo que habia de hacerse" (ib., 6-7).

$\mathrm{Y}$, volvamos al brillo áureo de la obra mosaica:

Besalel hizo el arca de madera de acacia,... La revistió de oro puro por dentro y por fuera... Hizo las barras de acacia, y las revistió 
de oro, hizo el propiciatorio de oro puro, dos querubines de oro, de oro batido, hizo la mesa de madera de acacia,... . La revistió de oro puro... Hizo el reborde de oro, de un codo de alto, y en él una moldura de oro, hizo todos los utensilios de la mesa, sus platos, sus cazoletas, sus copas y sus tazas para las libaciones, todo de oro puro (Éxodo 37 1-16).

Si bien, el tabernáculo de Moisés justifica por anticipado esta actitud de ofrenda, reiterada por el pueblo creyente a través de los siglos, será Salomón quien fije el arquetipo ideal, al construir su templo de 959 a 952, a.C. ${ }^{15}$ mismo que destruyó Nabucodonosor de Babilonia en 586 a.C.

El templo salomónico ha quedado en las escrituras como el gran símbolo de la construcción inspirada por Dios, santificada por $\mathbf{E} 1$ y extremadamente suntuosa para hacer su agrado como ofrenda.

$\mathrm{Su}$ desaparición implica su permanencia como inspiración ya que, de esta manera, revive y se multiplica con frecuencia, sin necesidad de repetición precisa. Como sucedió con los sucesivos templos erigidos en Jerusalén, y posteriormente aflora con frecuencia en toda la historia de la arquitectura cristiana, para tener un resurgimiento apoteótico, consciente $e$ intencional, en el catolicismo contrarreformista, como vimos anteriormente.

Así, el salomonismo como idea simbólico-artística, encontró su forma de mayor prestigio en el barroco, estilo que pujante y adaptable hizo del "orden divino", especialmente durante el siglo xvil y principios del Xvirl, si no su modalidad exclusiva, sí el estandarte más significativo desde el punto de vista universalista del estilo.

¡Cómo sorprende, emociona y se explical, que desde en los grandes monumentos metropolitanos, hasta en los más escondidos templos de remotos pueblecillos, muy acentuadamente en tierras hispánicas, aparezcan las torzas columnas animando con su giro los ricos paramentos y por sobre todo, cubiertas de oro, invadan los interiores y se combinen con otras formas de estructura arquitectónica con tal profusión, variedad y esplendor ornamental, que las referencias sacras al gran templo construido un milenio antes de Cristo parecen casi descripciones literales de infinidad de nuestros templos barrocos, donde resuenan ecos de áureo tono con vibración de ya tres milenios que, justamente por su dorada intemporalidad, el tiempo no les puede acallar (figura 2).

15 André Parrot. El templo de Jertusalén. Ediciones Garriga, S. A., Barcelona, 1961, p. 13. 
¿Cuántos presbiterios, con sus retablos dorados recuerdan el debir del templo salomónico y podrían describirse con palabras de las escrituras!:

Dispuso dentro, en lo más interior de la casa, el debir para el arca de la alianza de Yavé. El debir tenía veinte codos de largo veinte codos de ancho y veinte de alto. Hizo un altar de madera de cedro para delante del santuario, y lo recubrió de oro puro. Toda la casa la recubrió de oro puro, de arriba abajo, y recubrió también de oro todo el altar que estaba ante el santuario (Reyes I. 6 19-22).

Recordamos que con frecuencia al Sagrario con el Sacramento de la Eucaristía se le llama "nueva arca de la alianza" y, que la idea cúbica del Escorial coincide también con la forma cuadrada del debir salomónico y huelga el comentario al total recubrimiento de oro que se extiende por sobre toda la ornamentación, que a su vez se extiende por todas partes (figura 3):

Hizo esculpir todo en torno de la casa en los muros, por dentro y por fuera, querubines, palmas y guirnaldas de flores. También recubrió de oro el piso de la casa, lo mismo en el espacio interior que en el exterior. A la entrada del santuario hizo una puerta de dos hojas, de madera de olivo, y el dintel y las jambas eran de cinco esquinas. Las dos hojas eran de madera de olivo y talladas con entalladuras de querubines, palmas y botones de flores; y todo; querubines, palmas y botones de flores, cubierto de oro (Reyes 1. 6 29-32).

Es indudable que, en el hurgar escriturístico, los constructores del barroco hallaron más de un incentivo para sus obras, las que ast adquieren un respaldo sacro, a la vez que les quedan las puertas de la creación abiertas a su fantasía, por lo que uno de sus mayores méritos es el estudio y respeto al pasado buscando actualizarle sin autoesterilizarse pues, bien podemos comprobar cómo estas descripciones sólo se interpretan, y no se siguen literalmente. Los templos barrocos, hasta en su modalidad más definidamente salomónica, no hacen arqueologismos, y es digno de tomarse en cuenta que, en todo el proceso de la arquitectura cristiana y en el salomonismo más recrudecido, nunca, que sepamos, se ha tratado de reproducir el histórico templo en su forma original.

No se trata, pues, de un renacimiento de lo hebraico sino de actualizar en forma permanente, e insistimos, en forma católica - universaltodo lo que procede de inspiración divina. 
La historia sirve de apoyo no al prejuicio, sino al desenfado creativo. Arqueología de símbolos que no se anquilosan. Encuentros con el pasado, sin lastres académicos.

\section{El áureo barroco}

Como si nacer en cuna refulgente fuera lo más natural; como Cristo nace de la casa real de David; el barroco cristiano, hereda bienes ancestrales que usufructa y administra a su manera.

La idea del oro le es natural, pero de este oro trascendente, por eso desde el siglo xviı, el padre José del Valle en su sermón con motivo de la dedicación de la Capilla del Rosario en Puebla se dirige a los fieles, a sabiendas de que el sentido alegórico de sus barrocos giros se sobrentiende:

Dedicarle esta aseada Capilla de oro a María N. Señora ... es empeñarla a que no sólo comunique a sus esclavos y cofrades el oro de sus perfecciones, sino que también los ampare... luego si María Santísima es casa de oro... Es el oro fuerte, y Madre de donde nacen los más ricos quilates de sus tesoros... porque es Maria oro puro... Madre del más fino oro... en buena hora este católico pueblo... dedique, consagre a tan Sagrada Madre... este magnífico templo, tan suntuosa capilla, que labró el oro más fino de la devoción... ${ }^{18}$

Desde luego que aparte de ser intencional el sentido alegórico del exceso decorativo barroco, este simbolismo se predicaba y enseñaba, como nos lo prueba la "Octava maravilla". ${ }^{18} \mathrm{Y}$ se deseaba, como lo dijo el predicador José Salgado Somosa:

Se transladen, se copien, se esculpan en nuestros corazones las purezas que idean de esta fábrica los adornos, ya que contienen en sí, invisiblemente reseñas del poder de la majestad de Dios. ${ }^{17}$

16 Octaya maravilla del Nuevo Mundo en la gran Capilla del Rosario. Dedicada y aplaudida en el convento de N.P. S. Domingo de la ciudad de los Angeles. El dia 16 del mes de abril de 1690. Puebla, 1690. La cita anterior la extracta Justino Fernández en El Retablo de los Reyes. IIE. UNAM, México, 1959, p. 55.

17 Francisco de la Maza. Con apoyo en la Octava maravilla... interpretó y publi. có "La decoración simbólica de la Capilla del Rosario de Puebla", en Anales del IIE., UNAM., ท, 23. México, 1955, p. 10. De donde sabemos que a fray Agustín Hernández "se debe el primor de esta arquitectura, a su desvelada atención la valentía de sus jeroglificos y a su elevado espíritu lo bien trazado de sus misterios". Octava Maravilla, fol. 162. 
En el siglo xvin, y como culminación evolutiva del estilo, modalidades como el barroco estípite o churrigueresco, ya ni se molestan en justificar su triunfal presencia dorada; la dan por sentada como resultado de su progenie. $Y$, con ufana razón y teológica seguridad, sus obras efervescen de riqueza material, artística y alusiva cuando se percatan que en la propia Biblia el Señor, al referirse a las sucesivas reconstrucciones del templo Santo en Jerusalén, ya no sólo del salomónico, que fue destruido, sino de los que posteriormente se le erigen y consagran los acepta diciendo:

Mía es la plata, mío es el oro, dice Yavé, El Señor dios de los ejércitos. La gloria de esta postrera casa será más grande que la de la primera, dice Yavé, Señor Dios de los ejércitos y en este lugar daré Yo la paz (Ageo 2 9-10).

¡Y con qué emotiva fruición se grita a la calle, en pleno auge constructivo de mediados del siglo xviII, que este Nuevo Mundo, esta Nueva España, se renueva en base a su religiosidad!

Con fecha de 1743 , se data la portada del palacio episcopal en la ciudad de México (figura 4). Esta portada, flanqueada por cuatro hermosas pilastras estípites, de trazo puramente geométrico, pues no llevan adornos vegetales, animales ni humanos, acogen entre ellos la inscripción latina:

$\begin{array}{ll}\text { DIXIT } & \text { ECCE } \\ \text { QUI } \cdot & \text { NOVA } \\ \text { SEDEBAT } & \text { FACIO } \\ \text { IN } & \text { OMNIA } \\ \text { THRONO } & \text { AP. } 21\end{array}$

Que no es sino la cita apocalíptica del capítulo 21, versículo 5, que transcrita al español es:

$Y$ dijo el que estaba sentado en

el trono: "He aquí que hago

nuevas todas las cosas."

$Y$ quien renueva todas las cosas sentado en el trono es Cristo, por consecuencia; este mundo nuevo se renueva por y para Cristo, y así debieron sentirlo quienes al labrar esta portada también leían este otro párrafo, que es continuación de la cita: 


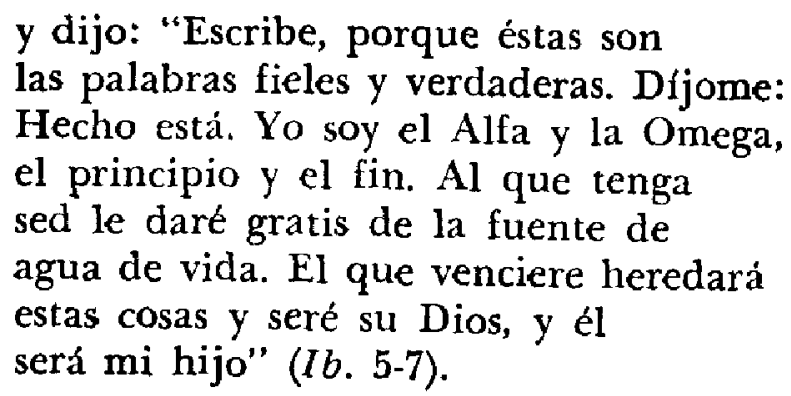

Como en todo lo apocalíptico, un sentido premonitorio de grandeza tienen estas frases, y tal parece que, como ordena el que está "sentado en el trono": "Escribe, porque éstas son las palabras fieles y verdaderas" se hizo cumplir su orden como si igualmente dijera: "Construye, pinta, esculpe ... con arte fiel y verdadero", tal fue la euforia creativa, no exenta de un nacionalismo en ciernes, a la que se entregaron estas tierras, durante el siglo xvır, cuando miles de iglesias, pletóricas de oros coruscantes, fueron erigidas (figura 5).

$\mathbf{Y}$ puesto que, para explicarnos la presencia del oro en el barroco, de citas y frases se ha tratado, terminamos con la frase de Cristo que tan podría ser principio como es final de estas páginas, palabras indiscutibles, solemnes y definitivas que, por sf solas, bastan para sacudir nuestra mezquindad y aclarar las dudas, o la incertidumbre que tene. mos respecto al uso y valoración del más hermoso y noble de los metales:

$$
\begin{aligned}
& \text { [Insensatos y ciegos! } \\
& \text { ¿qué vale más, el oro } \\
& \text { o el templo que santifica el oro? } \\
& \text { Mateo, } 23 \text { (17). }
\end{aligned}
$$

